\title{
ir
}

\section{LA IMAGEN DE DÁNAE EN EL MÁGICO PRODIGIOSO DE CALDERÓN: TERENCIO, SAN AGUSTÍN Y FRAY MANUEL DE GUERRA Y RIBERA}

\author{
Frederick A. de Armas \\ University of Chicago \\ [Anuario calderoniano (ISSN: 1888-8046), 1, 2008, pp. 87-104]
}

El mágico prodigioso es una de las pocas comedias de santos que ha sido canonizada por la crítica. Elogiada por los románticos alemanes, y traducida y adaptada por Percy B. Shelley y por Edward Fitzgerald en Inglaterra, la obra continúa representándose en la escena mundial ${ }^{1}$.

${ }^{1}$ En Francia, por ejemplo, Jean-Jacques Préau la tradujo al francés y junto con Jacques Nichet realizó la escenografía para el Teatro de la Villa en París en 1991, verdadera "apuesta» pues según Jean Canavaggio la obra nunca se había representado en Francia (Canavaggio, 2003, p. 49). Contrastando con esta representación donde hay pocos recortes y el sermón cristiano se transforma según Canavaggio en «un himno a la libertad inalienable del ser humano» (Canavaggio, 2003, p. 52), tenemos la versión mexicana en dos actos de Álvaro Custodio. Su Mágico prodigioso apareció en la cartelera del teatro Milán de la Ciudad de México en marzo de 1960. Custodio, exiliado español y fundador de la Compañía de Teatro Clásico de México, quiso representar sólo la esencia de la obra, la conversión de Cipriano. Como explica Montserrat Gibert Cardona su versión se enfoca en «el enredo que conduce a Cipriano a conocer y aceptar la verdad» (Gibert Cardona, 1992, p. 956) — esto es, la existencia del Dios cristiano. Eliminando toda acción secundaria, desechando los graciosos, y sólo preservando tres personajes, Cipriano, Justina y el demonio, Custodio recorta la obra para llegar casi a un breve auto sacramental, a un sermón en el que se demuestra 
Ya que la trama conduce a la conversión de un filósofo pagano al cristianismo, la obra puede estudiarse como un choque de religiones, de códigos y de imágenes. Parece como si Calderón, al contrario de muchos de sus textos, casi no "adornara» su obra con citas de la mitología clásica ${ }^{2}$. Pero las pocas alusiones que se incluyen, son claves para comprender la polivalencia con las que se representan, aún en una comedia de santos.

Hay quienes insisten en que el decorativismo mitológico «puede ayudarnos a comprender el hecho de que convivan los mitos cristianos y los mitos paganos, es decir, dos religiones... sin que eso fuera entendido como un problema de confluencias» ${ }^{3}$. Para otros críticos, la mitología se convierte en código, sea ya político, erótico o religioso. Y se discute si en estos códigos se vacía o no el contenido inicial de los mitos ${ }^{4}$. En un ensayo reciente, Curlo aduce que el mito de Apolo y Dafne puede detectarse en los comienzos de la leyenda de Justina y Cipriano. Menciona, por ejemplo, que Antioquía, donde se desarrolla la acción, tenía un gran templo dedicado a Apolo, y que: «El paraje más deleitoso de las afueras se le nombró Dafne» ${ }^{5}$. Curlo encuentra resonancias del mito en la comedia calderoniana y así muestra orígenes paganos, contactos y confluencias.

cómo un filósofo pagano puede eventualmente rechazar las ilusiones del demonio y convertirse al cristianismo. Esto es lo contrario de lo que haría Préau que sólo elimina unos cien versos y trabaja para recobrar en francés el «orden, acrobático a veces, de las palabras» y «el léxico de las pasiones» (Canavaggio, 2003, p. 50). Mientras que Préau se basa en la edición publicada en el xvII, obra que transforma el original para hacerlo más asequible a los tablados madrileños, Custodio también utiliza algo de la representación original en Yepes para la fiesta de Corpus Christi de 1637. Es por esto por lo que la versión mexicana comienza con un parlamento del demonio en el cual expone claramente su propósito. La obra pasa inmediatamente a la definición de la deidad propuesta por Plinio, la cual no corresponde a las acciones del supremo dios pagano, Júpiter. El examen de los dioses paganos y sus faltas, llevarán a la conversión de Cipriano.

2 Entre las pocas referencias mitológicas en El mágico prodigioso encontramos a Argos, Júpiter (vv. 12, 176, 1139), Minerva (v. 2891), Narciso (v. 1826), los Tritones (v. 1244), y Venus (v. 2891).

${ }^{3}$ Díez Borque, 2003, p. 65.

${ }^{4}$ Creo que hoy día estamos muy concientes de la importancia de los dioses paganos y de los múltiples niveles interpretativos de las comedias mitológicas. Ver, por ejemplo, De Armas, 1986, y Greer, 1991.

${ }^{5}$ Curlo, 2002, p. 135. 
En este ensayo quisiera estudiar otro mito como elemento clave en El mágico prodigioso. Para comprender su importancia, debemos pasar a la Sexta parte de las comedias de Calderón publicada con enmiendas por Juan de Vera Tassis y Villarroel, dos años después de la muerte del dramaturgo, donde se incluye El mágico prodigioso ${ }^{6}$. Para rendir homenaje a Calderón, la edición de Vera Tassis incluye la famosísima "Aprobación» del trinitario Fray Manuel de Guerra y Ribera, que ya había aparecido también en la Verdadera quinta parte. Para Luciano García Lorenzo, esta obra es importantísima pues «las argumentaciones del Padre Guerra suponen un magnífico compendio cercano ya al final del XVII, de las polémicas iniciadas cien años antes» ${ }^{7}$. La obra, según Carine Herzig, engendró «el episodio polémico más encarnizado de toda la controversia ética cobre la licitud de la comedia, y dando lugar, entre 1682 y 1684, a la redacción, la edición o la reedición de unos 18 textos ${ }^{8}$. Ya se ha discutido en detalle la deuda de Guerra a Tomás de Aquino9 9 Y también otros han tratado en detalle los problemas políticos que llevaron a que este trinitario, del partido de don Juan José de Austria, fuera condenado por todo un gru-

${ }^{6}$ La primera impresión conocida de la obra aparece en Parte veinte de comedias varias nunca impresas, compuestas por los mayores ingenios de España veinte años antes. Según McKendrick, la edición de 1653 «is a corrupt text, full of misprints, omissions and errors... the reworking was done hastily, possibly in response to a pressuring commission which did not allow Calderón time for careful syllable and line counts» (McKendrick, 1992, p. 17).

7 García Lorenzo, 1995, p. 67. Guerra pronunció el elogio fúnebre de Calderón en 1681, y al siguiente año publicó su «Aprobación», en la que utiliza mucho las críticas del padre Pedro Puente Hurtado de Mendoza (1631). Las críticas a su «Aprobación» fueron muchísimas e incluyen romances satíricos. La respuesta de Guerra permaneció inédita hasta el siglo dieciocho. Cuando en 1751 el padre Francisco Moya y Correa vuelve a criticarlo «se exhumarán en Valencia parte de los papeles inéditos del Padre Guerra, apareciendo, en 1752, el volumen Apelación al tribunal de los doctos» (García Lorenzo, 1995, p. 66). También en el siglo XVIII, como explica Thomas O’Connor, Fray Agustín Sánchez retomó la aprobación de Guerra en 1750 para volver a condenar el teatro clásico e intimar que la comedia moderna era en cierto sentido aún peor (O'Connor, 2000, pp. 131-32). Posiblemente como respuesta a éste, a Moya y Correa y a otros ataques contra la comedia, don Juan Fernández de Apontes en 1760, vuelve a publicar el texto de la "Aprobación» de Guerra frente a su edición de las comedias de Calderón.

${ }^{8}$ Herzig, 2005, p. 96.

${ }^{9}$ Ver por ejemplo Vitse, 1988, pp. 64, 66. 
po de jesuitas ${ }^{10}$. Lo que me interesa de su tratado es su relación icónica, moral, y mitológica con El mágico prodigioso de Calderón.

Aunque Guerra va a alabar el teatro de Calderón, como predicador, se siente obligado a censurar los vicios aun aquellos que tienen que ver con el teatro ${ }^{11}$. Guerra sabe muy bien que: «hombres muy sabios, y de virtud muy ceñida predican y publican gravísimos daños de las comedias. Lo general en que se fundan es decir que son reprobadas de los Santos Padres... que son una escuela de incontinencia y lascivia» ${ }^{12}$. Para resolver el dilema de cómo alabar a Calderón, Guerra comienza con una detallada historia del teatro de Grecia y Roma. Guerra decide criticar a los clásicos con vehemencia. Ya que la tragedia proviene de festivales a Baco y la comedia se basa en festejos a Apolo, su origen se relaciona con dioses falsos y con rudezas ${ }^{13}$. Aun cuando pasan a Roma, estos "deliciosos teatros» ${ }^{14}$ siguen teniendo como propósito la idolatría "para aplacar sus falsas deidades» ${ }^{15}$. La crítica al teatro por parte de San Agustín y otros padres de la Iglesia se basa, según Guerra, en tres elementos: su institución o establecimien-

${ }^{10}$ Juan José de Austria era hijo ilegítimo de Felipe IV y la actriz María Calderón y desea el poder después de la muerte de Felipe IV en 1665, cuando Mariana de Austria gobierna. Del partido de la reina es el jesuita austriaco Juan Everard Nithard, quien se enfrenta con don Juan y con nuestro trinitario. Otro jesuita, Agustín de Herrera, tiene una reacción más literaria que política. Le critica a Guerra que mucho de su material ser nada original. Ver también la carta anónima de 1682 contra Guerra, analizada por Marc Vitse (Vitse, 1988, pp. 146-62).

${ }^{11}$ La aprobación de Guerra puede dividirse en dos partes: «la legitimidad teológica y utilidad política del teatro en general y, en la segunda, de manifestar la excelencia ética y estética del teatro de Calderón» (Herzig, 2005, p. 97). Yo diría que en realidad podríamos añadir como primera parte o introducción la historia del teatro en la antigüedad.

${ }^{12}$ Herzig, 2005, párrafo 7. Aunque he consultado la reimpresión del sexto tomo de 1683 publicada en 1973 y la edición de 1760, utilizo aquí la edición de Carine Herzig que aparece en su artículo sobre la obra. La referencia es a los párrafos numerados que aparecen, según Herzig en la reimpresión de esta Aprobación en el capítulo quinto de Apelación al tribunal de los doctos (1752).

13 Herzig, 2005, párrafo 9.

14 Herzig, 2005, párrafo 11.

15 Herzig, 2005, párrafo 12. Repite luego que Tertuliano «toma por basa de su discurso y fundamento que no era lícito frecuentar los teatros por haber tenido su origen en la idolatría» (Herzig, 2005, párrafo 24). 
to, su estilo, y su daño ${ }^{16}$. Por institución se entiende que se escribe para «aplacar la ira de sus dioses ${ }^{17}$, o sea que tiene como fundamento la idolatría. En segunda instancia, el teatro clásico está escrito con estilo que hace deleitoso lo pecaminoso. Su conclusión es que causa daño a la religión cristiana y a las costumbres ${ }^{18}$. Nos cuenta que era tal la afición al teatro en la antigüedad, que los emperadores cristianos no pudieron controlarla ${ }^{19}$. Como ejemplo clave, de cómo los romanos llegaron a "canonizar los vicios» ${ }^{20}$ a través de las acciones de los dioses, alude a una comedia de Terencio siguiendo las palabras de San Agustín: «En la comedia de vuestro Terencio, se excusa el perdido joven del adulterio, mirando la tabla de Júpiter, cuando en lluvia de oro bajó para conquistar a Dánae» ${ }^{21}$. Continúa con un resumen de la maldad de los dioses parafraseando a San Cipriano: «Describen a Venus lasciva, a Marte adúltero, a Júpiter mayor príncipe de sus vicios, que por sus reinos, ardiendo con sus rayos en feos amores, ya le blanquean como cisne, ya le doran con la lluvia de Dánae, ya le sirven ministros las aves para arrebatar a su amado Ganímedes» ${ }^{22}$.

No hay por qué detenernos mucho más en el análisis de Guerra. Su técnica es la de contrastes. Rechaza el teatro clásico pagano con gran furor y erudición para mostrar sus credenciales de casto, cristiano y riguroso clérigo. Pasa entonces al contraste, preguntándose si las modernas y cristianas comedias «no son tan opuestas como tinieblas y luces» ${ }^{23}$. Divide el teatro moderno (y en realidad el de Calderón) en tres tipos: comedias de santos, de historia y de capa y espada, señalando cómo los tres tipos «se ciñen a las leyes de la modestia, que no son peligro sino doctrina» ${ }^{24}$. La primera provoca la ternura, la segunda infunde ejemplos y la tercera lleva a la pureza o castidad. El te-

16 Herzig, 2005, párrafo 19.

17 Herzig, 2005, párrafo 20.

18 Esto se debe a los errores de sus dioses: «los latrocinios de Mercurio, las lascivias de Venus, las corrupciones de [...] deidades» (Herzig, 2005, párrafo 25).

19 «Entraron los restantes emperadores en un mar tan tormentoso, que como diestros pilotos, cedieron a la furia del viento, y se dejaron llevar de el agua» (Herzig, 2005, párrafo 22).

${ }^{20}$ Herzig, 2005, párrafo 54.

21 Herzig, 2005, párrafo 54.

22 Herzig, 2005, párrafo 58.

23 Herzig, 2005, párrafo 88.

24 Herzig, 2005, párrafo 90. 
atro de Calderón es entonces algo positivo para la moral y la política de su tiempo ${ }^{25}$. Reitera una y otra vez cómo: «Personas (bien discretas cierto) me han jurado que los mueve más una comedia destas [de santos] que un sermón» ${ }^{26}$. Concluye alabando al «monstruo de ingenio» ${ }^{27}$ Calderón, que en vez de seguir a los más famosos de los antiguos, comenzando con Enio y concluyendo con Virgilio, «los miró no para seguirlos, sino para adelantarlos ${ }^{28}$, escribiendo obras que sirven de ejemplos y dan $« \tan$ discreta la medicina ${ }^{29}$.

Este tratado, considerado como revolucionario por algunos críticos contemporáneos ${ }^{30}$, puede servir de crítica y de nuevo acercamiento a El mágico prodigioso. Calderón y Guerra utilizan muchos de los mismos tópicos. Por ejemplo: (1) el teatro como idolatría; (2) el contraste entre luz y tinieblas (con la alusión a Apolo, dios solar e iniciador de la comedia); (3) el teatro antiguo como «iglesia del Diablo, templo del demonio» ${ }^{31}$; (4) la metáfora del teatro pagano como tormenta; y (5) las acciones inmorales de los dioses paganos. Y es la imagen de Dánae y el impacto de las imágenes lo que más nos interesa ${ }^{32}$.

${ }^{25}$ Para Guerra, el teatro tiene función política: «Debo el fundamento a quien lo debo todo, que es a Santo Tomás: no dijo que era algún juego útil, sino "necesario", porque lo que es necesario, es indispensable, y conveniente. Conviene entretener los ánimos o cansados o ociosos... [con] empleos que diviertan los entendimientos inquietos, y quejosos» (Herzig, 2005, párrafo 117). Añade que discutirá esto con más detenimiento en su Teatro de las pasiones. Este texto está perdido, aunque Herzig apunta que «disponemos del cap. 1 del Libro Primero, publicado en 1752 por Gonzalo Xaraba al final de la Apelación al Tribunal de los Doctos» (Herzig, 2005, p. 138, nota 228).

${ }^{26}$ Herzig, 2005, párrafo 145.

27 Herzig, 2005, párrafo 173.

${ }^{28}$ Herzig, 2005, párrafo 177.

${ }^{29}$ Herzig, 2005, párrafo 182.

30 O'Connor considera que el tratado de Guerra fue verdaderamente revolucionario: «shocked some of his fellow clerics who held firmly to the Augustinian view that sexual love was fundamentally corrupt and only permitted after the fall for the continuation of the race. To assign to human sexuality a positive, moral, social and personal value was indeed revolutionary» (O'Connor, 2000, p. 49).

${ }^{31}$ Herzig, 2005, párrafo 24.

32 A todo esto podría añadirse la curiosa mención de un San Cipriano justamente después del ejemplo de Dánae y que sirve para apoyar los vicios de los dioses. También es curioso que la Sexta parte comience con Las fortunas de Andrómeda y Perseo, comedia mitológica representada en el Buen Retiro en la que aparece Dánae en escena, como madre de Perseo. 
La comedia de Calderón comienza con dos de los elementos subrayados por Guerra: la idolatría (la imagen de Júpiter) y la luz de Apolo. Las primeras palabras de Cipriano tienen que ver con la fiesta a Júpiter que se celebra en Antioquía. Pero El mágico prodigioso se aparta de la idolatría cuando Cipriano decide quedarse en el campo meditando sobre la filosofia en vez de asistir a la fiesta pagana. Al alejarnos de Antioquía no presenciamos ni la estatua del dios ni se nos ofrece la descripción de la imagen. Lo único que tenemos es una écfrasis alusiva, una referencia a la estatua y al nuevo templo, que tendría el espectador que visualizar en su propia imaginación. O sea que la imagen no tiene sustancia. En este sentido ya Cipriano anticipa uno de sus grandes descubrimientos hacia el final de la obra - la imagen erótica o pagana como vanitas (vv. 2542-2543).

También en el primer acto vemos cómo la llegada del demonio se asocia con el atardecer (las tinieblas) y sus futuras acciones recuerdan que el teatro pagano es descrito por Guerra como «templo del demonio». La misma Justina, en la obra asevera que la imagen de Júpiter en el nuevo templo «es el demonio» (v. 535) ${ }^{33}$. Se podría argüir que, a pesar de las muchas apariencias y confusiones creadas por el demonio a través de la obra, el texto calderoniano parece que nunca le pertenece, pues confiesa al final todas sus burlas, ordenado así por el divino autor. Por otra parte, la comedia mantiene el choque de códigos ya que, sin burlas del demonio, no tendríamos obra de teatro.

Otro elemento que menciona Manuel de Guerra es la presencia de la tormenta como metáfora del teatro pagano. Calderón la utiliza de manera muy efectiva para causar admiración y también para reforzar el sentido metafórico de la obra. La tormenta se relaciona con el mal, con el demonio, quien aparece como náufrago, y al final de la obra como "disforme monstruo» (v. 3100) que confiesa sus delitos. Así, la oposición luz y tinieblas tiene que ver con el contraste binario de la obra, con la luz divina y las confusas ignorancias del demonio. Pero, la arquitectura de la obra, como explica T. E. May, contiene «ironically hinted meanings ${ }^{34}$. Debemos recordar que el sol como Apolo es un

33 Claro que un auditorio erudito comprendería que la palabra «daemones» no era nada negativa en la antigüedad; Sócrates tenía su propio demonio, o sea, su guardián o musa.

34 May, 1986, p. 195. 
dios pagano de quien era devoto el emperador Constantino, y que esto facilitó su conversión al cristianismo; y que el cuarto planeta, se había utilizado, durante la época en que Calderón escribió su obra, como código mitológico para alabar al rey Felipe IV. Así, la luz no es sólo posesión del dios cristiano. Le pertenece a Apolo y a Felipe. Lo primero revelaría que los mitos no se han vaciado de su contenido y lo segundo podría llevar a meditaciones políticas. El diablo explica cómo «un rey, el mayor de todos... me llamó valido suyo» (vv. 1304, 1311). El público podría muy bien recordar que tal valido o privado, era para Felipe IV, el Conde-Duque de Olivares. Se podría así pensar cómo el valido era demoníaco y soberbio ${ }^{35}$.

Ahora bien, Cipriano, supuestamente va a desmentir la mitología con su filosofía. De esta manera, parece que se reducen aún más los substratos clásicos de Apolo y de Júpiter. Cipriano utiliza una cita de Plinio el Viejo para definir a la deidad. Aunque la crítica se ha preguntado por qué no utiliza a Platón, Aristóteles u otro filósofo más conocido, asevera T. E. May: «Calderón is skillful in the governing of the attention. A quotation from Plato or Aristotle would have set too many minds off after conventional philosophical hares... Coming unexpectedly from Pliny, the definition carries no such risk» ${ }^{36}$. Así el auditorio puede concentrarse en la definición:

Dios es una bondad suma una esencia, una sustancia, todo vista y todo manos.

(vv. 169-171) $)^{37}$

Esta cita de la Historia naturalis (libro II, capítulo 5), como explica Melveena McKendrick, no es una traducción literal, sino una adaptación de las muchas que ya existían en el Renacimiento español ${ }^{38}$. Se

35 Recordemos que en 1635, dos años antes de la primera versión de El mágico prodigioso, Calderón escribe El mayor encanto, amor donde la figura de Circe viene a representar a Olivares (De Armas, 1986, pp. 139-49).

36 May, 1986, p. 200.

37 Cito de la edición de B. W. Wardropper.

38 En la traducción inglesa de Plinio leemos: «Whoever God is — provided there is a god - and in whatever region he is, he consists wholly of sense, sight and hearing, wholly of soul, wholly of mind, wholly of himself. To believe in gods without 
insertan aquí elementos escolásticos cristianos tales como el summum bonum y el causa causarum ${ }^{39}$. Calderón sutilmente transforma la cita de Plinio para proponer elementos teológicos adecuados a la comedia de santos y al auto sacramental. Pero, de nuevo, el lector erudito puede meditar sobre las brechas textuales. Lo que no revela Calderón es que la definición de Plinio ocurre durante una disquisición sobre el sol en su Historia naturalis. Así, penetra Apolo/Sol dentro del texto, iluminando visiones paganas ${ }^{40}$.

Creo que hay más. El concepto del summum bonum es el que le lleva a dudar a Cipriano de que Júpiter sea el dios verdadero. Le explica al demonio disfrazado de galán:

\author{
No hallar \\ el dios de quien Plinio trata; \\ que si ha de ser bondad suma, \\ aun a Júpiter le falta \\ suma bondad, pues le vemos \\ que es pecaminoso en tantas \\ ocasiones: Dánae hable \\ rendida, Europa robada.
}

(vv. 173-180)

En esto notamos de nuevo un eco de Plinio, quien exclama que es locura pensar que el Dios supremo tendría vicios humanos. Lo que no incluye Plinio son los dos ejemplos específicos dados por Cipriano. Los nombres de Dánae y Europa resaltan en esta obra, pues, como ya mencionamos, El mágico prodigioso tiene pocas (pero importantes) referencias mitológicas a pesar de que el texto se sitúa en un ambiente

number, and gods corresponding to men's vices as well to their virtues... reaches an even greater height of folly» (Pliny, Natural History, ii.5). McKendrick apunta a una posible fuente para las alteraciones: Gloso litteralis in Plinii primum et secundum naturalis historiae libris de F. López de Villalobos (Alcalá, 1524).Ver McKendrick, 1992, p. 51, nota 38 .

39 "Since he is the first cause of all things, then goodness in him must be goodness in supreme form... God is the single cause of all his creation, he himself being uncaused, and omniscience ("all seeing") and omnipotence ("all hands") are his attributes» (McKendrick, 1992, pp. 51-52).

40 El segundo libro de Plinio trata del «mundo» y del «cielo». Aquí incluye los elementos, los planetas y el sol, que se compara con la deidad. Tenemos además descripciones de los eclipses y los cometas. 
pagano, Antioquía, bajo el emperador $\mathrm{Decio}^{41}$. O sea que debemos añadir estos nuevos mitos. Ambos son metamorfosis del dios supremo de los griegos y romanos.

Como hemos mencionado, Manuel de Guerra presenta detalladamente los daños de la imagen de Dánae. Parece bien claro que Guerra no ha leído a Terencio, y sólo conoce su comedia El Eunuco a través de los comentarios de San Agustín. Para Guerra, la pintura de Júpiter transformado en lluvia de oro para poder raptar a Dánae lleva al joven al adulterio. No es así (no hay adulterio), y tampoco lo dice Agustín $^{42}$. El joven va tras Pámphila disfrazado de eunuco, pero solo después de ver la pintura de Júpiter disfrazado de lluvia de oro, el galán decide imitarlo y raptar a Pámphila. El ejemplo de San Agustín tiene como fin explicar que el dios supremo, Júpiter, ha inspirado lascivia y violencia. Pero ni Guerra ni San Agustín mencionan que Pámphila era esclava.Vale recordar el tratamiento hacia los esclavos en Roma por cristianos y paganos. Que la obra acabe felizmente cuando se descubre que Pámphila es hija de un ciudadano ateniense, no significa para la época la falta de justicia poética ya que habría casi tanta distancia entre un dios y un ser humano como entre un ciudadano y una esclava. Ambas son relaciones de poder. Claro que esto para nada le resta poder a la imagen que se contempla.Y es esa écfrasis una importante clave tanto para los antiguos como para los modernos.

Al igual que la imagen, el teatro es un deleite para la vista, y la Contra-Reforma reconocía el gran poder de la imagen para retenerse en la memoria, para exaltar las pasiones. Por esto, Juan de Pineda, durante el reinado de Felipe II, recuerda otra vez la imagen de Dánae utilizada por Terencio y condenada por San Agustín, recriminando no sólo a los dramaturgos, sino también a los pintores y príncipes: «y no nos queda sino cualificar tan gran pecado de pintores desalmados, y el descuido de los príncipes que no castigan cosa tan perjudicial en el

${ }^{41}$ Decio persiguió a los cristianos y fue emperador entre 249 y 251 . La presencia de Decio ocurre en algunas versiones de la leyenda de San Cipriano al confundirse con San Cipriano de Cartago. El Cipriano de Antioquía sufrió el martirio bajo el emperador Diocleciano (284-305). Ahora bien, la Iglesia Católica hoy día considera estos eventos como leyenda piadosa y no como hechos históricos.

42 «Hence the young profligate in Terence... accepts this as authoritative precedent for his own licentiousness, and boasts that he is an imitator of God» (Augustine, The City of God, p. 46). 
reino» ${ }^{43}$. No cabe duda de que Pineda sabía muy bien que años antes, cuando Felipe era todavía príncipe, Tiziano le había pintado una Dánae. Ésta, con otras mitologías, incluyendo la Europa también de Tiziano (y citada por Calderón), tenía como destino el camerino privado de Felipe y servirían para su delectación ${ }^{44}$. Civil y Ginzburg han recalcado que la imagen de Dánae era supuestamente el summum del erotismo en el Siglo de Oro ${ }^{45}$. Conociendo muy bien la reputación erótica de esta imagen mitológica, Tiziano había pintado otra Dánae para el cardenal Farnese. En ella el cardenal podía deleitarse observando que el modelo era su propia amante ${ }^{46}$. Y, Lope de Vega, como ha mostrado Margaret Greer, utiliza la pintura de Tiziano para realzar el erotismo de su comedia El Perseo ${ }^{47}$. La breve alusión calderoniana tiene pues una larga historia. Aunque el dramaturgo ha destilado todo elemento ecfrástico de la disquisición filosófica de Cipriano, queda todavía el sustrato erótico-pagano tan bien recobrado por Tiziano ${ }^{48}$. Sólo su mención bastaría para recordar que su sensualidad pagana servía de deleite a cardenales italianos y galanes de la antigüedad; y que la preciada Dánae se encontraba en el palacio de los Habsburgos españoles. No faltarían preguntas sobre la relación entre la pintura y Felipe IV.

Claro que Calderón, al igual que Guerra, insiste en utilizar la unión de Júpiter y Dánae para mostrar el mal ejemplo de los dioses paganos. Pero en el Renacimiento y aún en la Contra-Reforma, estas dei-

43 Pineda, Diálogos familiares de la agricultura cristiana, XXII, p. 66.

44 No sabemos si el camerino de Felipe con estas pinturas mitológicas existió en realidad. Sobre el futuro de la pintura, escribe Vosters: «En 1623 probablemente ya estaba en el Alcázar de Madrid... Cabe suponer que Rubens la viera en el Alcázar en 1603-4» (Vosters, 1990, p. 39).

45 «Muy famoso en la época, el tema de Dánae y Júpiter se consideraba como la representación erótica por antonomasia. San Agustín había utilizado para condenar las pinturas lascivas el ejemplo de un personaje de una comedia de Terencio excitado a la vista de tal cuadro" (Civil, 1990, p. 46).

46 Talvacchia, 1999, p. 46.

47 "The first shows Danae reclining on a couch as a golden rain descends from a cloud and her old servant holds her apron to catch it. Lope's play recalls this scene as Danae's maid servant loads her apron to catch it. Elisa exclaims: "Ay, señora, coger quiero estas uríferas perlas!"” (Greer, 1991, p. 44).

48 Curiosamente, Calderón parece hacer algo parecido en su comedia palaciega de espectáculo, Las fortunas de Andrómeda y Perseo: "Calderón shows Perseo and the audience the golden rain as a flashback that Perseo dreams» (Greer, 1991, p. 62). 
dades parecían sobrevivir bajo nuevos disfraces. El título de Júpiter servía para halagar a príncipes y los retratos de Dánae se escondían en sus palacios. Cipriano parece rechazar a Júpiter dado que le falta el summum bonum al raptar a Dánae, pero esto es también uno de los juegos irónicos de la comedia. En realidad Cipriano trata de convertirse en un nuevo Júpiter para poder conseguir los favores de su Dánae/Justina. Este «juego» mitológico esconde códigos de poder y de deseo que se aproximan a las imaginaciones del joven en la obra de Terencio. Por más que se depure la materia prima y se trate de acrisolar la visión pagana en el martirio cristiano, el poder de la imagen como talismán y como símbolo clásico se resiste. Y Dánae, esa peligrosa imagen, según los moralistas, se convierte en el mismo eje de la acción de la comedia.

Claro que el demonio responde a la acusación de Cipriano contra las acciones de Júpiter. Prestémosle atención:

\author{
Estas son falsas historias \\ en que las letras profanas \\ con los nombres de los dioses \\ entendieron disfrazada \\ la moral filosofia.
}

(vv. 185-189)

Aquí el demonio describe la manera en que los dioses paganos, en palabras de Jean Seznec sobrevivieron en el Cristianismo. Las repetidas alegorías sobre los dioses creaban una «filosofia moral» a través de cuyos enigmas se podía leer y observar texto y figura pagana. De este modo, podríamos visualizar el rapto como raptus místico en el que un dios penetra el ser humano, mostrando su gloria.Y justamente de este mito se hicieron múltiples interpretaciones. Juan Pérez de Moya ${ }^{49}$, por ejemplo, en su Philosophía secreta (1585), explica el significado moral del mito: "corrompida de Júpiter en figura de lluvia de oro es dar a entender que este metal fuerza los altísimos muros, y los castísimos pechos». Si volvemos a observar la pintura de Tiziano, podríamos ver

${ }^{49}$ Pérez de Moya, Comparaciones o símiles para los vicios y virtudes, p. 782. Pérez de Moya también explica que por esta fábula «quisieron los poetas declarar que lo que 
todos estos significados, y sobre todo el último, pues la vieja criada de Dánae con un saco trata de recoger algo del oro destinado a su ama.

El rechazo de Cipriano ante la interpretación alegorizante puede llevarnos a pensar que Calderón, con cierta ironía se está aquí refiriendo a sus muchas fiestas palaciegas donde representa fábulas de los dioses en comedias de gran espectáculo. Las palabras de Cipriano también pueden aplicarse a las controversias sobre el arte renacentista, controversia que subsiste hoy día. Mientras que para muchos las pinturas mitológicas esconden un enigma, un saber, un misterio, para otros sólo esconden una aproximación íntima al mundo pagano, pleno de erotismo. Podemos ver esta oposición en los acercamientos de Erwin Panofsky y de Bette Talvacchia ${ }^{50}$. Explica Talvacchia que: "Without the "cloak of mythology," the nude image... would have been more than unseemly» ${ }^{51}$. Ella expone cómo Giulio Romano, Jacopo Caraglio y otros artistas del Renacimiento: «successfully employed a formula for legitimizing erotic representation through the use of mythological references $»^{52}$. Calderón, muy conciente del poder de la imagen, nos lleva a reflexionar sobre las imágenes de los dioses paganos.

Según Thomas Mathews, el siglo cuarto había comenzado una guerra de imágenes entre el cristianismo y el paganismo ${ }^{53}$. Poco a poco los artistas se dieron cuenta de que con imágenes cristianas podían contrarrestar las numerosas pinturas y esculturas de dioses paganos. Algo parecido ocurrió con la Contra-Reforma en el siglo XVI. El concilio de Trento se preocupó por las imágenes y trató de prohibir los desnudos mitológicos. Por otra parte, querían dar ímpetu a imágenes cristianas para incitar la devoción. Los jesuitas, en particular, utilizaron la visualización y la imagen, comenzando con los Ejercicios espirituales

de Dios está determinado en ninguna manera se puede evitar» (Pérez de Moya, Comparaciones o símiles para los vicios y virtudes, p. 782).

50 Aunque Panofsky acepta el erotismo de la obra (Panofsky, 1969, p. 144), explicita mucho más las interpretaciones morales (Panofsky, 1969, p. 145), y hasta las religiosas. En la Dánae española ella se convierte «into a chosen vessel destined to give a savior to the world» (Panofsky, 1969, p. 150).

51 Talvacchia, 1999, p. 46.

52 Talvacchia, 1999, p. 161.

53 «The fourth century ushered in a war of images. What made the ill - knit Christian works of art [...] more potent than works of a centuries - old tradition of the most sophisticated accomplishment?» (Mathews, 1993, p. 10). 
de Ignacio de Loyola y continuando con toda una serie de frescos y altares decorados para iglesias jesuitas ${ }^{54}$. Lo que se pedía era la participación activa del observador. Esto es justamente lo que hace Cipriano. Comprende que, si Dios es «todo vista» entonces tiene que, en las palabras de Melveena McKendrick, "penetrate the meanings of the universe by seeing» ${ }^{55}$. Con fina ironía, Calderón hace que esta visualización lo lleve a captar la belleza física de Justina. Y en la comedia Cipriano sigue los pasos del galán de la comedia de Terencio. Quiere convertirse en un nuevo Júpiter (habiendo visualizado su poder sobre Dánae), quiere conseguir el poder de la magia con la ayuda del demonio, para así poseer a Justina.Y también como el galán terenciano, Cipriano pretende rebajarse ante Justina - no con disfraz de eunuco, sino con uno de falsa humildad y resignación ${ }^{56}$. Al igual que en el mito, Júpiter (ahora el diablo) penetra las paredes de la torre/casa de Dánae/Justina. Su propósito es llevarla a Cipriano. De nuevo, Calderón explica muy bien el proceso, que tiene que ver con la imagen e imaginación. Es la imagen de Cipriano/Júpiter la que casi persuade a Justina. Como explica el demonio: «En haberlo imaginado / hecha tienes la mitad» (vv. 2299-2300). Pero, Justina usa de su «libre albedrío» (v. 2320) para desviarse de lo imaginado. Es así que el demonio tiene que crear la falsa imagen de Justina. La obra de Calderón se desvía de Terencio presentando: «Un yerto cadáver mudo» (v. 2342), ejemplo de vanitas. La meditación activa sobre esta imagen, y el recuerdo del summum bonum (v. 2673) trae consigo la conversión de Cipriano. La obra, como la de Terencio, acaba con la unión de los amantes, pero aquí esta unión sólo ocurre con el martirio, al profesar su nueva religión frente al emperador pagano ${ }^{57}$. Cipriano se ha convertido en el

54 «The Jesuits brought these spaces to life through the extensive fresco and altarpiece cycles that adorned their interiors... Complex, erudite, and reflective, these illustrative series placed the emphasis on viewers, encouraging active participation and individual response through meditation, prayer and imagination" (O'Maley, 2003, p. 125). Margaret Greer subraya cómo Calderón también se refiere a la «composición de lugares» descrita por San Ignacio (Greer, 1991, p. 54).

55 McKendrick, 1992, p. 52.

56 Justina siente «piedad» por él ya que «vive ausente por mí» (v. 2262).

57 «Que en la muerte te querría / dije; y pues a morir llego / contigo, Cipriano, ya / cumplí mis ofrecimientos» (vv. 3046-3049). 
«mágico de los cielos» (v. 3140) que asciende las esferas hacia el Sol divino.

Mientras que la imagen del martirio, según el padre Guerra, sirve para crear la ternura y para mover al auditorio a la devoción, la visión de un ascenso por las esferas se esfuerza en borrar la dorada transformación de Júpiter y la modalidad pagana del Sol como Apolo. Recordemos que el mismo Ignacio de Loyola tenía visiones solares ${ }^{58}$. El choque de las imágenes no puede ser más claro.Y, aunque la obra se esfuerza por llenar de nuevos contenidos los ídolos paganos y de convertir en tinieblas y en demonios los dioses de la antigüedad, un residuo de idolatría permanece en el texto. El amor entre Cipriano y Justina ha triunfado al igual que en Terencio. Justo antes del martirio, Justina llama a Cipriano «ilusión de mi deseo» (v. 2998). Y este deseo, tan aborrecido en la obra, sigue su curso, sea en luminosos cuadros renacentistas, en esquemas de comedias clásicas o en palacios reales, donde los reyes se deleitan con pinturas de Tiziano y con nombres paganos de Júpiter y Sol que resaltan sus talismánicos poderes y sus magias parciales.

58 «The founder of the Society of Jesus also experienced visions, among them visions of cloudbursts with rays of the sun emanating from them» (O'Malley, 2003, p. 125). 


\section{Bibliografía}

Augustine, Saint, The City of God, trad. M. Dods, Nueva York, The Modern Library, 1950.

Calderón de la Barca, P., Comedias del célebre poeta español don Pedro Calderón de la Barca, [...] que saca a luz don Juan Fernández de Apontes, vol. 1, Madrid, Viuda de Don Manuel Fernández, 1760.

- El mágico prodigioso, ed. B. W. Wardropper, Madrid, Cátedra, 1985.

- Sexta parte de comedias del célebre poeta español don Pedro Calderón de la Barca, [...]. Sacada de sus originales que publica la amistad de don Juan de Vera Tassis y Villarroel, Madrid, Francisco Sanz, 1683, reimpresión, Hant, Gregg Internacional Publishers, 1973.

Canavaggio, J., "Una escenografia de El mágico prodigioso», en Teatro calderoniano sobre el tablado. Calderón y la puesta en escena a través de los siglos. XIII Coloquio Anglogermano sobre Calderón. Archivum Calderonianum 10, ed. M. Tietz, Stuttgart, Franz Steiner Verlag, 2003, pp. 49-61.

Civil, P., "Erotismo y pintura mitológica en la España del Siglo de Oro», Edad de Oro, 9, 1990, pp. 39-49.

Cotarelo y Mori, E., Bibliografía de las controversias sobre la licitud del teatro en España, Madrid, Revista de Archivos, Bibliotecas y Museos, 1904.

Curlo, V., «El tema de Cipriano y Justina releído desde sus orígenes mitológicos hasta El mágico prodigioso de Calderón», en Calderón 2000. Homenaje a Kurt Reichenberger en su 80 cumpleaños, ed. I. Arellano, Kassel, Edition Reichenberger, 2002, vol. II, pp. 133-142.

De Armas, F. A., The Return of Astraea: An Astral-Imperial Myth in Calderón, Lexington, University of Kentucky Press, 1986.

- Cervantes, Raphael and the Classics, Cambridge, Cambridge University Press, 1998.

- «Painting Danae, Diana, Europa and Venus:Titian and Argensola's $A$ Nuño de Mendoza», Calíope, 6, 2000, pp. 181-97.

Díez Borque, J. M., «Encuentros escénicos de los dioses en Calderón de la Barca», en Teatro calderoniano sobre el tablado. Calderón y la puesta en escena a través de los siglos. XIII Coloquio Anglogermano sobre Calderón. Archivum Calderonianum 10, ed. M. Tietz, Stuttgart, Franz Steiner Verlag, 2003, pp. 63-83.

García Lorenzo, L., «Ideología y moralismo. El padre Manuel de Guerra y Ribera y su aprobación a las comedias de Calderón de la Barca», en III y IV Jornadas de Teatro, Burgos, Universidad de Burgos, 1995, pp. 61-71.

Gibert Cardona, M., "El mágico prodigioso. Adaptación en dos actos de la obra del mismo nombre de D. Pedro Calderón de la Barca», en Actas del $X$ Congreso de la Asociación Internacional de Hispanistas, Barcelona, PPU, 1992, pp. 955-968. 
Ginzburg, C., Clues, Myths, and the Historical Method, trad. J. y A. Tedeschi, Baltimore, The Johns Hopkins University Press, 1989.

Grant, M., Constantine the Great. The Man and his Times, Nueva York, Charles Scribner's Sons, 1993.

Greer, M. R., The Play of Power. Mythological Court Dramas of Calderón de la Barca, Princeton, Princeton University Press, 1991.

Herrera, A. de (Don Antonio Puente Hurtado de Mendoza), Discurso teológico y político sobre la apología de las Comedias, que ha sacado a luz el Reverendísimo P. M. Fr. Manuel Guerra, con nombre de aprobación de la quinta, y sexta parte de las Comedias de don Pedro Calderón, sin fecha.

Herzig, C., "Fray Manuel de Guerra y Ribera, Aprobación de la Verdadera Quinta parte de Comedias de don Pedro Calderón. Estudio, edición y notas", Criticón, 93, 2005, pp. 95-154.

Mathews, T. S., The Clash of Gods. The Reinterpretation of Early Christian Art, Princeton, Princeton University Press, 1993.

May, T. E., "The Symbolism of El mágico prodigioso», en Wit of the Golden Age. Articles on Spanish Literature, Kassel, Edition Reichenberger, 1986, pp. 194212.

Mariana, J. de, Tratado contra los juegos públicos. Obras del padre Juan de Mariana, Biblioteca de autores españoles, vol. 31, Madrid, Rivadeneyra, 1854.

McKendrick, M. (in association with A. A. PArker), "Introduction», El mágico prodigioso de Pedro Calderón de la Barca, Oxford, Clarendon Press, 1992, pp. 1-72.

O’Connor, T. A., "Antecedentes inmediatos de la "Aprobación" del Padre Guerra: El "Discurso de la vida y escritos de don Agustín de Salazar" de Vera Tassis», en El escritor y la escena VII. Estudios sobre teatro español y novohispano de los Siglos de Oro: Dramaturgia e Ideología, Ciudad Juárez, México, Universidad Autónoma de Ciudad Juárez, 1999, pp. 159-67.

- Love in the "Corral». Conjugal Spirituality and Anti-theatrical Polemic in Early Modern Spain, New York, Peter Lang, 2000.

O'Malley, J. W. y G. A. Bailey, The Jesuits and the Arts. 1540-1773, Filadelfia, Saint Joseph's University Press, 2003.

Panofsky, E., Problems in Titian. Mostly Iconographic, Nueva York, New York University Press, 1969.

Pérez de Moya, J., Comparaciones o símiles para los vicios y virtudes. Pilosofía secreta, Madrid, Biblioteca Castro, 1996.

Pineda, J. de, Diálogos familiares de la agricultura cristiana, Biblioteca de autores españoles, vol. 169, Madrid, Atlas, 1964.

Pliny, Natural History, trad. H. Rackham, Loeb Classical Library, vol 1, Cambridge, Massachusetts, Harvard University Press, 1979.

Talvacchia, B., Taking Positions. On the Erotic in Renaissance Culture, Princeton, Princeton University Press, 1999. 
Vitse, M., Eléments pour une théorie du théâtre espagnol du XVII Siècle, Toulouse, France-Iberie Recherche / Université de Toulouse-Le Mirail, 1988.

Vosters, S. A., Rubens y España. Estudio artístico-literario sobre la estética del Barroco, Madrid, Cátedra, 1990. 